\title{
Determinan Pendapatan Rumah Tangga Muslim
}

\author{
Febrida Khairani' ${ }^{1}$, Delima Sari Lubis ${ }^{2}$, Rodame Monitorir Napitupulu3 \\ 123Institut Agama Islam Negeri Padangsidimpuan \\ Email:febridakhairani@gmail.com, delimasarilubis@gmail.com, \\ rodamemonitorir@gmail.com, \\ Jl. HT. Rizal Nurdin KM.4,5 Sihitang, Padangsidimpuan
}

\begin{abstract}
The background of the problem in this study is that in addition to being a wife in a family, women also play a role as housewives, meaning that women manage all household matters. Women who work precisely in the Environment I of Kayu Ombun Village to fulfill their daily needs, help their husbands ease their burden in earning a living due to the large number of family members, and to increase family income. This study aims to determine the effect of working women, education level, and family members on Muslim household income. Women working according to Sanderson K Stepen is a new feminist awareness that women can meet family income. The level of education according to Sudharjo is the education owned by a worker is the basic capital needed to carry out work. Family Members, according to Mantra, are all family members who are included in the workforce group. Home income according to Boserup Ester is the total income of all family members to meet shared needs. This research is a quantitative research. Data collection instruments used a questionnaire with a sample of 50 women. . The analytical tool used is the validity and reliability test, normality test, linearity test, classic assumption test, multiple linear regression analysis, coefficient of determination test, and hypothesis testing. Based on the research results, working women have no effect on family income, while the level of education and family members have a positive and significant effect on family income. Simultaneously testing (working) women working, education level, and family members have a significant effect on family income.
\end{abstract}

\section{Keywords: Determinant, Income, Working Woman}

\begin{abstract}
Abstrak
Latar belakang masalah pada penelitian ini adalah dalam sebuah keluarga selain berperan sebagai istri, wanita juga berperan sebagai ibu rumah tangga, artinya wanitalah yang mengatur segala urusan rumah tangga.Wanita yang bekerja tepatnya di Lingkungan I Kelurahan Kayu Ombun untuk memenuhi kebutuhan hidup sehari - hari, membantu suami meringankan bebannya dalam mencari nafkah akibat banyaknya anggota keluarga, serta untuk menambah pendapatan keluarga. Penelitian ini bertujuan untuk mengetahui pengaruh wanita bekerja, tingkat pendidikan, dan anggota keluarga terhadap pendapatan rumah tangga muslim. Wanita bekerja menurut Sanderson K Stepen adalah suatu kesadaran feminis yang baru bahwa wanita dapat memenuhi pendapatan keluarga.Tingkat pendidikan menurut Sudharjo adalah pendidikan yang dimiliki seorang pekerja merupakan modal dasar yang dibutuhkan untuk melaksanakan pekerjaan.Anggota Keluarga menurut Mantra adalah seluruh jumlah anggota keluarga yang sudah termasuk dalam kelompok tenaga kerja.Pendapatan rumah menurut Boserup Ester adalah jumlah pendapatan keseluruhan dari seluruh anggota keluargauntuk memenuhi kebutuhan bersama. Penelitian ini merupakan penelitian kuantitatif.Instrumen pengumpulan data menggunakan angket dengan jumlah sampel 50 orang wanita. . Alat analisis yang digunakan adalah uji validitas dan reliabilitas, uji normalitas, uji linearitas, uji asumsi
\end{abstract}




\section{Determinan Pendapatan Rumah Tangga Muslim}

Febrida Khairani

klasik, analisis regresi linier berganda, uji koefisien determinasi, dan uji hipotesis. Berdasarkan hasil penelitian wanita bekerja tidak berpengaruh terhadap pendapatan keluarga sedangkan tingkat pendidikan dan anggota keluarga berpengaruh positif dan signifikan terhadap pendapatan keluarga. Dilakukan pengujian secara bersamaan (simultan) wanita bekerja, tingkat pendidikan, dan anggota keluarga berpengaruh signifikan terhadap pendapatan keluarga.

Kata Kunci: Determinan, Pendapatan, Wanita Bekerja

\section{Pendahuluan}

Kesejahteraan Keluarga adalah suatu kondisi dinamis keluarga dengan terpenuhinya semua kebutuhan fisik materil, mental spiritual dan sosial, yang memungkinkan keluarga dapat hidup wajar sesuai dengan lingkungannya serta memungkinkn anak-anak tumbuh kembang dan memperoleh perlindungan yang diperlukan untuk membentuk sikap mental dan kepribadian yang mantap dan matang sebagai sumber daya manusia yang berkualitas. Sedangkan dari pandangan yang berbeda dinyatakan bahwa keluarga sejahtera adalah keluarga yang dibentuk berdasarkan atas perkawinan yang sah, mampu memenuhi kebutuhan hidup spiritual dan materiil yang layak, bertaqwa kepada Tuhan Yang Maha Esa, memiliki hubungan yang serasi, selaras dan seimbang antar anggota dan antar keluarga dengan masyarakat dan lingkungan (Undang-Undang Republik Indonesia No. 52 tahun 2009). Taraf Kesejahteraan tidak hanya berupa ukuran yang terlihat (fisik dan kesehatan) tapi juga yang tidak dapat dilihat (spiritual). Ferguson et al. menyatakan bahwa kesejahteraan keluarga dapat dibedakan kedalam dua macam yaitu: kesejahteraan ekonomi (family economic well-being) dan kesejahteraan material (family material well-being). Kesejahteraan ekonomi keluarga, diukur dalam pemenuhan akan input keluarga (pendapatan, upah, aset dan pengeluaran).

Sementara kesejahteraan materiil diukur dari berbagai bentuk barang dan jasa yang diakses oleh keluarga (Puspitawati, 2013:7). Konsep kesejahteraan sangat berkaitan dengan konsep kebutuhan,dengan terpenuhinya kebutuhan, maka seseorang sudah dapat dinilai sejahtera. Karena tingkat kebutuhansecara tidak langsung sejalandengan indikator kesejahteraan. Teori Maslow menggambarkan rumusan tentang kebutuhan yang hierarkis dalam bentuk segitiga, dimana kebutuhan yang ada di atas akan terpenuhi setelah kebutuhan di bawahnya terpenuhi. Tingkatan paling bawah dalam hierarkis kebutuhan tersebut adalah kebutuhan fisik yang menyangkut 
kebutuhan pokok seperti sandang, pangan dan papan. Kemudian berturut-turut adalah kebutuhan akan rasa aman, kebutuhan sosial dan kebutuhan penghargaan atas diri (Nitisusastro, 2013:46-54). Keluarga yang sejahtera merupakan keluarga yang dapat memenuhi segala kebutuhannya, dan disebut sebagai keluarga berkualitas, dengan terpenuhinya kebutuhan dalam aspek pendidikan, kesehatan, ekonomi, sosial budaya, kemandirian keluarga dan mental spiritual serta nilai-nilai agama.

Saat ini peran wanita semakin luas dan kompeten tidak hanya mengurusi wilayah domestik rumah tangga saja. Banyak wanita bekerja pada sektor ekonomi dan dapat menambah penghasilan keluarga seperti banyaknya kaum wanita yang bekerja di kantor, di pabrik- pabrik, jualan di pasar, serta ada pula wanita yang sukses menempati sektor-sektor publik, dengan menjadi Bupati, Walikota, Gubernur bahkan kepala Negara atau pemerintahan. Sehingga dapat dikatakan bahwa jumlah wanita yang terlibat dalam kegiatan mencari nafkah semakin besar (Siti Khiomah, 2013).

Dalam masa sekarang ini sudah banyak ditemukan wanita- wanita yang bekerja, sejatinya terlebih khusus untuk ibu rumah tangga peran pokok seorang istri dalam rumah tangga merupakan mengurusi urusan rumah tangga.Peran pokok tersebut dengan menjadi ibu yang senantiasa memberikan teladan yang baik bagi anak-anaknya, dan menjadi istri yang berbakti kepada suami.Namun jika kondisi ekonomi keluarga belum mencukupi untuk memenuhi semua kebutuhan rumah tangga.Maka peran seorang istri bertambah dengan ikut berperan serta dalam meningkatkan pendapatan keluarga.Semakin tinggi minat masyarakat untuk meningkatkan pendapatan rumah tangga semakin banyak jumlah wanita yang bekerja.

Pada dasarnya pendapatan rumah tangga berasal dari berbagai sumber, kondisi ini bias terjadi karena masing - masing anggota rumah tangga mempunyai lebih dari satu jenis pekerjaan baik sebagai pekerjaan tetap maupun pekerjaan pengganti. Pendapatan seseorang pada dasarnya berasal dari tiga macam sumber meliputi: (1) berasal dari gaji atau upah yang diterima sebagai imbalan tenaga kerja, (2) berasal dari hak milik yaitu modal, tanah, dan sebagainya, dan (3) berasal dari pemerintah (Hanifah Ammaturrohim, 2015). Pendapatan yang diperoleh wanita yang berkeluarga akan memberikan kontribusi terhadap perekonomian keluarga. Kontribusi pendapatan istri terhadap keluarga tidak akan sebesar kontribusi pendapatan suami terhadap 


\section{Determinan Pendapatan Rumah Tangga Muslim}

Febrida Khairani

pendapatan keluarga, karena upah yang diterima wanita lebih kecil dari pria (Asriyani, dkk., 2017).

Di Kelurahan Kayu Ombun terutama di lingkungan I sudah banyak wanita yang bekerja dengan berbagai jenis pekerjaan untuk menambah pendapatan keluarga guna memenuhi kebutuhan hidup sehari-hari. Padahal bukan tidak mungkin upah atau gaji yang mereka peroleh sama atau bahkan melebihi dari yang diperoleh suami mereka. Namun besarnya pengaruh wanita bekerja, tingkat pendidikan dan jumlah anggota keluarga atau tanggungan keluarga terhadap pendapatan rumah tangga masyarakat muslim. Hal ini yang mendasari penulis untuk melakukan penelitian yang berjudul. “Determinan Pendapatan Rumah Tangga Muslim”.

\section{Tinjauan Teoritik}

Kebutuhan merupakan segala sesuatu yang mampu memberikan rasa aman dan nyaman pada seluruh anggota keluarga. Tingkatan kebutuhan yang harus dipenuhi menurut Kuswardinah (2007:18-20) yaitu; (1) kebutuhan jasmani, adalah kebutuhan pokok keluarga dan alat, barang serta uang yang digunakan untuk memudahkan aktifitas sehari-hari; (2) kebutuhan rokhani, adalah kebutuhan yang mencakupi agama dan pendidikan; (3) kebutuhan sosial psikologis, adalah kebutuhan manusia sebagai makhluk sosial serta dorongan emosi yang menimbulkan perasaan seperti: sedih dan gembira; (4) dan kebutuhan kesehatan, berupa kesehatan jasmani dan kesehatan rokhani.

Tidak jauh berbeda dengan Maslow (1943) dalam bukunya yang berjudul Theory of human motivation mengidentifikasikan kebutuhan dalam bentuk yang hierarkis kedalam lima tingkatan (Nitisusastro, 2012:46-54) yaitu; (1) kebutuhan fisik (physical need), adalah kebutuhan akan makan, minum, tempat tinggal dan bebas dari rasa sakit; (2) kebutuhan rasa aman (safety need), adalah kebutuhan akan kebebasan dari ancaman, yakni aman dari ancaman kejadian atau lingkungan; (3) kebutuhan sosial (sosial need), adalah kebutuhan kehidupan sosial dan rasa cinta, yakni: kebutuhan akan teman, afiasi, interaksi dan cinta, (4) kebutuhan harga diri (estemneed), adalah kebutuhan akan penghargaan diri dan penghargaan dari orang lain; (5) kebutuhan perwujudan diri (self-actualization need), adalah kebutuhan untuk memenuhi diri sendiri dengan memaksimumkan penggunaan kemampuan, keahlian dan potensi. 
Pada dasarnya jenis kebutuhan yang disebutkan oleh beberapa ahli mempunyai banyak kesamaan. Berbagai kebutuhanperlu dipenuhi oleh setiap keluarga dalamhidupnya, agar tujuan keluarga dalammencapai keluarga sejahtera dapat terwujud.Kondisi kesejahteraan keluarga terjadi pada suatu keadaan ketika keluarga dapat memenuhi segala macam kebutuhannya baik kebutuhan fisik, spriritual, materiil maupun sosial sehingga keluarga dapat hidup sesuai dengan lingkungannya hingga mencapai kepuasan dan kemakmuran.

Pendapatan rumah tangga adalah penghasilan dari seluruh anggota keluarga yang disambungkan untuk memenuhi kebutuhan bersama ataupun perorangan adalah rumah tangga.Menurut Biro Pusat statistik (BPS), pendapatan yang diterima seseorang tidak hanya berupa uang tetapi dapat berupa barang atau lainnya.Pendapatan berupa uang merupakan penghasilanyang diterima biasanya sebagai balas jasa, sumber utama gaji atau upah serta lain-lain balas jasa, misalnya dari atasan, pendapatan bersih dari usaha sendiri dan dari pekerjaan bebas.Pendapatan dari penjualan barang yang dipelihara dari halaman rumah, hasil investasi seperti modal tanah, uang pensiun, merupakan dalam bentuk barang dan jasa. Menurut Boserup Ester, pendapatan rumah tangga adalah jumlah pendapatan keseluruhan/rill dari seluruh anggota rumah tangga yang di sumbangkan untuk memenuhi kebutuhan bersama maupun perseorangan dalam rumah tangga (Marselina Fitriani, 2016).

Berdasarkan definisi pengertian diatas dapat disimpulkan bahwa pendapatan rumah tangga adalah pendapatan yang diperoleh dari seluruh anggota keluarga baik yang berasal dari kepala keluarga atau seluruh anggota keluarga. Pendapatan median seluruh rumah tangga adalah pendapatan diurutkan dari terendah hingga tertinggi.Pada suatu tahun tertentu, setengah dari rumah tangga berada di atas pendapatan median dan sisa setengahnya berada di bawah pendapatan median. Perbedaan Pendapatan antar rumah tangga juga berasal dari perbedaan jumlah pekerja dalam suatu rumah tangga (Wiliam A. Mc Earchern, 2001). Upah dan gaji yang biasa disebut dalam istilah asing wager dan salaries merupakan pendapatan yang diperoleh rumah tangga keluarga sebagai imbalan terhadap penggunaan jasa sumber tenaga kerja dalam pembentukan produk nasional, seperti tiunjangan perumahan (Masyuhri Machfudz, 2012). 


\section{Determinan Pendapatan Rumah Tangga Muslim}

Febrida Khairani

Dalam semua lapangan kerja, yang cocok dengan kodratnya, wanita juga dituntut untuk aktif bekerja, wanita tidaklah untuk duduk berpangku tangan atau tinggal berkurung dirumah sebagai makhluk Allah yang lemah yang harus dibantu dan dibelanjai oleh laki- laki.Banyak sekali lapangan pekerjaan yang cocok dengan wanita, hanya saja wanita harus selalu ingat, bahwa kewanitaannya itu tetap melekat pada dirinya. Artinya kodrat fisik dan cirri kewanitaan itu tetap berbahaya bagi dirinya dan terhadap orang lain, jika ia tidak sadar atau tidak menjaga dirinya.

Untuk kepentingan kesehatan jiwanya wanita itu harus gesit bekerja. Wanita yang tidak bekerja, baik di rumah maupun luar rumah, akan kehilangan akal untuk mengisi waktu, mungkin ia akan pergi bertandang kerumahtetangga atau tidur di rumah dan main- main tanpa arah. Akibatnya ia akan merasa bosan, kesal dan tidak tenang. Keadannya yang seperti itu akan menyebabkan suasana keluarga menjadi tegang dan pendidikan anak- anak akan terbengkalai. Oleh sebab itu wanita harus bekerja sesuai dengan kodrat dan kemampuannya.

Dalam asumsi tradisional tentang peremppuan pada stuktur sosial patriakis adalah perempuan dilihat dengan cara berbeda dengan pria, tetapi bukan berarti pembedaan dalam memperlakukan keduanya dibolehkan, keduanya mempunyai hak sebagai tenaga kerja yang sama. Pada hakikatnya wanita yang terlibat dalam pekerjaan setelah menikah karena membantu keluarga dalam hal finansial. Suami istri harus bekerja sama dalam berbagai tanggung jawab dalam mengurus kebutuhan rumah tangga anak. Oleh karena itu, tidak jarang seortang ibu rumah tangga juga bekerja di luar rumah demi menambah pemasukan ekonomi keluarga.

Pendapatan merupakan semua output yang dihasilkan atau bisa juga diartikan sebagai pendapatan yang diterima oleh seluruh pihak di dalam perekonomian. (Suherman Rosyidi, 2017). Menurut kamus akuntansi pendapatan adalah penerimaan uang tunai yang diperoleh selama jangka waktu tertentu, baik dari hasil penjualan barang maupun jasa atau piutang, ataupun dari sumber-sumber lain. (Sujana Ismaya, 2014). Financial accounting Standard Board, Statement No. 3 menjelaskan bahwa, "Pendapatan merupakan arus masuk atau peningkatan nilai aset dari suatu entitas atau 
gabungan keduanya selama periode tertentu yang berasal dari penyerahan atau produksi barang, pembelian jasa atau pelaksanaan kegiatan kerja utama perusahaan yang berjalan." (Islami Rahmi, 2014). Menurut Sadono Sukirno pendapatan adalah "penghasilan yang diterima tanpa memberikan suatu kegiatan apapun yang diterima oleh suatu negara”. (Sadono Sukirno, 2008). Pendapatan merupakan konsep aliran (flow concept). (Prathama Ramadhan, 2006).

Faktor yang mempengaruhi besarnya pengaruh wanita bekerja adalah tingkat pendidikan, jumnlah anggota keluarga serta pendapatan keluarga. Sedangkan faktorfaktor yang mempengaruhi pendapatan adalah: (Rozalinda, 2014).

1) Kesempatan kerja yang tersedia, semakin banyak kesempatan kerja yang tersedia, semakin banyak penghasilan yang bisa diperoleh dari hasil kerja tersebut.

2) Jenis pekerjaan, terdapat banyak jenis pekerjaan yang dapat dipilih seseorang dalam melakukan pekerjaannya untuk mendapatkan penghasilan.

3) Kecakapan dan keahlian, dengan bekal kecakapan dan keahlian yang tinggi akan dapat meningkatkan efisiensi dan efektivitas yang pada akhirnya pula terhadap penghasilan.

4) Motivasi atau dorongan juga mempengaruhi jumlah penghasilan, semakin besar dorongan untuk melakukan pekerjaan, semakin besar pula penghasilan yang diperoleh.

5) Keuletan bekerja

6) Banyak sedikitnya modal yang digunakan.

Menurut Boediono, faktor - faktor yang mempengaruhi pendapatan adalah sebagai berikut.

1) Jumlah faktor produksi yang dimiliki yang bersumber pada hasil - hasil tabungan tahun ini dan warisan atau pemberian.

2) Harga per unit dari masing - masing faktor produksi, harga ini ditentukan oleh penawaran dan permintaan di pasar fator produksi.

3) Hasil kegiatan oleh anggota keluarga sebagai pekerjaan sampingan. (Leni Novita, 2015).

Jika wanita dituntut untuk melaksanakan fungsi dan peranannya dalam semua lapangan hidup, maka wanita perlu berpegetahuan. Bagaimana mungkin 


\section{Determinan Pendapatan Rumah Tangga Muslim}

Febrida Khairani

wanita bodoh akan dapat menjadi tiang yang baik dan kokoh bagi suatu negara, seperti dikatakan oleh Nabi Muhammad SAW. Dan bagaimana pula caranya ia melaksanakan fungsi sebagai pendidik dan Pembina bagi anak- anaknya, dimana kebahagiaan atau surge bagi anaknya terpikul atas pundaknya, jika ia tidak berpengetahuan.

Menurut Sudharjo Tingkat pendidikan adalah tahapan pendidikan yang ditetapkan berdasarkan tingkat perkembangan peserta didik, tujuan yang akan dicapai dan kemauan yang dikembangkan. Pendidikan yang tinggi memudahkan seseorang atau masyarakat untuk menyerap informasi dan mengimplementasikannya dalam perilaku. Tingkat pendidikan yang dimaksud disini tingkat pendidikan ibu rumah tangga tersebut baik formal maupun informal (Marselina Fitriani,2016).

Pendidikan adalah suatu proses yang bertujuan untuk menambah keterampilan, pengetahuan, dan meningkatkan kemandirian maupun pembentukan kepribadian seorang individu. Pendidikan yang dimiliki seseorang pekerja merupakan modal dasar yang dibutuhkan untuk melaksanakan pekerjaan.Makin tinggi tingkat pendidikan yang dimiliki makin tinggi pula kemampuan mereka untuk bekerja.Produktivitas mereka ditunjang oleh pendidikan.

Keluarga adalah unit terkecil dari masyarakat yang dapat menjalankan berbagai fungsi dalam memenuhi kebutuhan kehidupannya, termasuk di dalamnya fungsi ekonomi, agar tercapai kesejahteraan dalam keluarga itu.Fungsi ekonomi memegang peranan penting dalam keluarga karena merupakan faktor dasar untuk menunjang kebutuhan fisik keluarga (Dadang Anshori.Pemenuhan fungsi ekonomi ini dapat dilakukan oleh suami maupun istri ataupun oleh keduanya.

Jumlah anggota keluarga sangat menentukan jumlah kebutuhan keluarga.Semakin banyak anggota keluarga berarti semakin banyak pula jumlah kebutuhan keluarga yang harus dipenuhi.Begitu pula sebaliknya, semakin sedikit anggota keluarga berarti semakin sedikit anggota keluarga berarti semakin sedikit pula kebutuhan yang harus dipenuhi keluarga.Setiap individu mempunyai kebutuhan sendiri. Sehingga dalam keluarga yang jumlah anggotanya banyak kebutuhankebutuhan akan banyak.

Menurut Mantra, jumlah anggota keluarga adalah seluruh jumlah anggota keluarga rumah tangga yang tinggal dan makan, makan dari satu dapur dengan kelompok penduduk yang sudah termasuk dalam kelompok tenaga kerja (Marselina 
Fitriani,2016). Jumlah anggota rumah tangga mencerminkan pengerluaran rumah tangga. Demikian pula jumlah anak yang tertanggung dalam keluarga akan berdampak pada besar kecilnya pengeluaran keluarga. Demikian juga anggota anggota keluarga yang cacat maupun lanjut usia. Anggota yang ditanggung yang tinggal bersama dalam satu rumah tangga serta makan dalam satu dapur menjadi tanggung jawab rumah tangga tersebut.Jumlah anggota keluarga pada penelitian ini adalah seluruh anggota rumah tangga termasuk anggota rumah tangga yang tertangung yang tinggal bersama dalam satu rumah dan makan satu dapur.

\section{Metode Penelitian}

Penelitian ini dilakukan di Kelurahan Kayu Ombun Padangsidimpuan tepatnya dilingkungan I Kelurahan Kayu Ombun, lokasi ini dipilih karena mayoritas wanita bekerja dan penduduknya adalah muslim. Penelitian ini dilakukan bulan Maret sampai dengan Desember tahun 2019. Penelitian ini mencakup dalam bidang tenaga kerja wanita, yaitu mengumpulkan data mengenai variabel determinan pendapatan rumah tangga muslim meliputi yaitu: wanita bekerja, tingkat pendidikan dan anggota keluarga, dengan mengumpulkan jurnal- jurnal, buku- buku yang berkaitan dan data primer dari ibu rumah tangga yang bekerja di dalam keluarga. Penelitian ini termasuk dalam penelitian kuantitatif dengan pendekatan deskriptif. Penelitian deskriptif adalah penelitian yang berusaha untuk menuturkan pemecahan masalah yang ada sekarang berdasarkan data- data, menyajikan data- data, menganalisis dan menginterpresentasikan (Sugiyono, 2015).

Populasi berasal dari kata bahasa Inggris Population, yang berarti jumlah penduduk(Burhan Bungin, 2011). Menurut Juliansyah Noor populasi adalah keseluruhan subjek penelitian (Juliansyah Noor, 2014) Dalam penelitian ini populasimya adalah semua wanita muslim yang bekerja di lingkungan I Kelurahan Kayu Ombun. Sampel adalah sebagian objek yang mewakili populasi yang dipilih dengan cara tertentu. Sampel juga merupakan bagian dari populasi yang akan diteliti $n=\frac{100}{1+100(0,10)^{2}}$ 


\section{Determinan Pendapatan Rumah Tangga Muslim}

$$
=50
$$

Febrida Khairani

Dengan demikian, jumlah sampel yang dibutuhkan adalah 50 orang wanita bekerja.

\section{Hasil dan Pembahasan}

Penelitian ini dilaksanakan di Kelurahan Kayu Ombun Kecamatan Padangsidimpuan Utara.Dimana Kelurahan Kayu Ombun ini merupakan salah satu Kelurahan yang terdapat di kecamatan Padangsidimpuan Utara Kota Padangsidimpuan Profinsi Sumatera Utara dengan luas wilayah 34Ha. Berdasarkan hasil uji yang dilakukan kepada masyarakat hasil uji normalitas bahwa nilai signifikansi (Asymp.Sig 2-tailed) sebesar 0,200. Nilai signifikansi lebih dari 0,10 $(0,200>0,10)$, jadi dapat disimpulkan bahwa nilai residual tersebut berdistribusi normal karena nilai Asymp.Sig 2-tailed lebih besar dari 0,10.

Hasil uji linearitas antara wanita bekerja dengan pendapatan keluarga memenuhi asumsi liniearitas dengan melihat nilai linier signifikan 0,226 $>0,10$. Maka dapat disimpulkan bahwa antara variabel wanita keluarga dengan pendapatan keluarga terdapat hubungan yang linier. Hasil uji linearitas antara tingkat pendidikan dengan pendapatan keluarga tersebut memenuhi asumsi linearitas dengan melihat nilai liniear signifikan $0,820>0,10$. Maka dapat disimpulkan bahwa antara variabel tingkat pendidikan dengan pendapatan keluargaterdapat hubungan yang linier. Hasil uji linieritas antara anggota keluarga dengan pendapatan keluarga tersebut memenuhi asumsi linieritas dengan melihat nilai liniear signifikan $0,043<0,10$. Maka dapat disimpulkan bahwa antara variabel anggota keluarga dengan pendapatan keluarga tidak terdapat hubungan yang linier.

Hasil uji multikolinearitas pada penelitian ini bahwa nilai VIF dari variabel wanita bekerja adalah $3,803<10$, variabel tingkat pendidikan adalah $4,6245<10$ dan variabel anggota keluarga $1,467<10$. Maka dapat disimpulkan tidak terjadi multikolinearitas antara variabel independen.

Metode yang digunakan dalam penelitian ini adalah Uji Glejser dilakukan dengan cara meregresikan antara variabel independen dengan nilai absolut residualnya (ABS_RES). Jika nilai signifikansi antara variabel independen dengan absolut residual lebih dari o,10 maka tidak terjadi masalah heteroskedasitas. Dari uji heteroskedastisitas 
diketahui bahwa nilai signifikansi ketiga variabel independen lebih dari o,10. Dengan demikian dapat disimpulkan bahwa tidak terjadi masalah heteroskedasitas pada model regresi.

Analisis regresi linear berganda menunjukkan:

a. Konstanta sebesar 2,938 mempunyai arti jika variabel wanita bekerja, tingkat pendidikan, dan anggota keluarga dianggap konstan atau nilainya o, maka pendapatan keluarga adalah sebesar 2,938.

b. Koefisien regresi $X_{1}$ (wanita bekerja) bernilai positif yaitu 0,095 dapat diartikan bahwa setiap wanita bekerja sebesar 1 satuan, maka akan meningkat pendapatan keluarga 0,095 satuan dengan asumsi variabel independen lain nilainya tetap.

c. Koefisien regresi $\mathrm{X}_{2}$ (tingkat pendidikan) bernilai positif yaitu 0,564 dapat diartikan bahwa setiap tingkat pendidikan sebesar 1 satuan, maka akan meningkat pendapaatn keluarga 0,564 satuan dengan asumsi variabel independen lain nilainya tetap.

d. Koefisien regresi $\mathrm{X}_{3}$ (anggota keluarga) bernilai positif yaitu 0,321 dapat diartikan bahwa setiap anggoya keluarga sebesar 1 satuan, maka akan meningkat pendapatan keluarga 0,321 satuan dengan asumsi variabel independen lain nilainya tetap.

Nilai R Square pada tabel diatas o,641 atau sama dengan 64,1\%. Hal ini menunjukkan bahwa persentasi sumbangan pengaruh variabel independen (Wanita Bekerja, Tingkat Pendidikan dan Anggota Keluarga) terhadap dependen (Pendapatan Keluarga) sebesar 64,1\%. Sedangkan sisanya sebesar 35,9\% (100\%-64,1\%) dipengaruhi dan dijelaskan oleh variabel lain yang tidak termasuk dalam penelitian ini.

Untuk mengetahui hasil signifikan atau tidak thitung dibandingkan tabel.thitung sebesar 0,640 dan ttabel sebesar 2,012 df (=n-k-1 atau 50-3-1=46) artinya bahwa thitung < $t_{\text {tabel }} 0,640<2,012$ dan signifikansi $<0,10$ yaitu $0,526>0,10$. Maka dapat disimpulkan hipotesis ditolak artinya wanita bekerja tidak berpengaruh terhadap pendapatan keluarga.thitung sebesar 2,536 dan tabel sebesar 2,012 df ( $=n-k-1$ atau 50-3-1=46) artinya

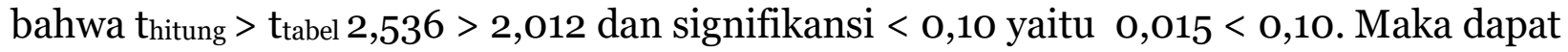
disimpulkan hipotesis diterima artinya tingkat pendidikan berpengaruh terhadap pendapatan keluarga.thitung sebesar 3,098 dan tabel sebesar 2,012 df (=n-k-1 atau 50-31=46) artinya bahwa thitung $>$ tabel 3,098 $>$ 2,012 dan signifikansi $<0,10$ yaitu $0,003<$ 


\section{Determinan Pendapatan Rumah Tangga Muslim}

Febrida Khairani

0,10. Maka dapat disimpulkan hipotesis diterima artinya anggota keluarga berpengaruh terhadap pendapatan keluarga.

Hasil uji simultan, dijelaskan bahwa $F_{\text {hitung }}$ adalah 27,400 sedangkan $F_{\text {tabel }} 2,81$.

Karena $F_{\text {hitung }}>F_{\text {tabel }}(27,400>2,81)$ dan tingkat signifikan yang diperoleh $0,000<$ 0,10 maka $\mathrm{H}_{\mathrm{a} 4}$ diterima, artinya terdapat pengaruh antara wanita bekerja, tingkat pendidikan dan anggota keluarga berpengaruh secara bersamaan (simultan) terhadap variabel dependen yaitu pendapatan keluarga di Kelurahan Kayu Ombun Kecamatan Padangsidimpuan Utara.

\section{Kesimpulan}

Berdasarkan hasil penelitian determinan pendapatan rumah tangga muslim maka dapat ditari kesimpulan sebagai berikut:

1. Tidak terdapat pengaruh variabel wanita bekerja terhadap pendapatan keluarga di Kelurahan Kayu Ombun. Karena $t_{\text {hitung }}<\mathrm{t}_{\text {tabel }}$ 0,640 $<$ 2,012 dan signifikansi 0,526 $>$ 0,10 .

2. Terdapat pengaruh variabel tingkat pendidikan terhadap pendapatan keluarga di Kelurahan Kayu Ombun. Karena thitung $>t_{\text {tabel }}(2,536>2,012)$ dan nilai signifikansi $0,015<0,10$.

3. Terdapat pengaruh variabel anggota keluarga terhadap pendapatan keluarga di Kelurahan Kayu Ombun. Karena $t_{\text {Hitung }}>t_{\text {tabel }}(3,098>2,012)$ dan nilai signifikansi $0,003<0,10$.

4. Terdapat pengaruh wanita bekerja, tingkat pendidikan, dan anggota keluarga secara simultan terhadap pendapatan keluarga di Kelurahan Kayu Ombun. Diperoleh $\mathrm{F}_{\text {Hitung }}>\mathrm{F}_{\text {Tabel }}(27,400>2,81)$ dan nilai signifikan $0,000<0,10$.

\section{Daftar Pustaka}


Asriyani, dkk."Kontribusi Pendapatan Tenaga Kerja Wanita Terhadap Pendapatan Keluarga Tani Padi Sawah" dalam jurnal Fakultas Pertanian Universitas Sumatera Utara, Vol 6, Nomor 1, 2017

Burhan Bungin, Metodologi Penelitian Kuantitatif Jakarta: Prenada Media,2011

Firdaus Muhammad, Ekonometrika Suatu Pendekatan Aplikatif Jakarta:PT Bumi Aksara, 2004

Fitriani Marselina," Pengaruh Wanita Bekerja Tingkat Pendidikan dan Jumlah Anggota Keluarga Terhadap Pendapatan Masyarakat Muslim Pada Kelurahan 20 ILIR Daerah IV Kecamatan ILIR Timur I Kota Palembang”, Palembang: Fakultas Ekonomi dan Bisnis Islam UIN Raden Fatah Palembang,2016

Hanifah Ammaturrohim. " Pengaruh Pendapatan dan Konsumsi Rumah Tannga Terhadap Kesejahteraan Keluarga Petani Penggarap Kopi Di Kecamatan Candiroto Kabupaten Temanggung Kabupaten Temanggung". Skripsi, Semarang: Fakultas Ekonomi Universitas Negeri Semarang, 2015.

Imam Ghozali, Aplikasi Analisis Multivariat dengan SPSS 23 Semarang: Universitas Diponegoro, 2013

Kantor Kelurahan Kayu Ombun Padangsidimpuan, 2019

Kuncoro Mudrajat, Metode Riset Untuk Bisnis dan Ekonomi Jakarta: Erlangga, 2009

Masyhuri Machfudz, Teori Ekonomi MakroMalang: UIN Maliki Press, 2012

Munir Misbahul, Produktivitas Perempuan Studi Analisis produktivitas Perempuan dalam Konsep Ekonomi Islam Malang: UIN Maliki,2010

Noor Juliansyah, Metodologi Penelitian Jakarta: Kharisma Putra Utama, 2014

Rahman Fazrul, Tentang Wanita Yogyakarta: Tazzafara,2002

Siti Khoimah, dkk. “ Kontribusi Pendapatan Tenaga Kerja Wanita Terhadap Pendapatan Rumah Tangga "Jurnal Fakultas Pertanian Universitas SumateraUtara, 2016.

Sugiyono, Metode Penelitian Bisnis Bandung: Alfabeta, 2015

Umar Husein, Research Methods in Finance and Banking Jakarta: PT. Gramedia Pustaka Media, 2002

Wiliam A. Mc Earchern, Ekonomi Mikro Jalarta: PT Salemba Emban Patria, 200 